\title{
Water relations of evergreen and drought-deciduous trees along a seasonally dry tropical forest chronosequence
}

\author{
Niles J. Hasselquist • Michael F. Allen • \\ Louis S. Santiago
}

Received: 26 February 2010/Accepted: 4 July 2010/Published online: 24 July 2010

(C) The Author(s) 2010. This article is published with open access at Springerlink.com

\begin{abstract}
Seasonally dry tropical forests (SDTF) are characterized by pronounced seasonality in rainfall, and as a result trees in these forests must endure seasonal variation in soil water availability. Furthermore, SDTF on the northern Yucatan Peninsula, Mexico, have a legacy of disturbances, thereby creating a patchy mosaic of different seral stages undergoing secondary succession. We examined the water status of six canopy tree species, representing contrasting leaf phenology (evergreen vs. droughtdeciduous) at three seral stages along a fire chronosequence in order to better understand strategies that trees use to overcome seasonal water limitations. The early-seral forest was characterized by high soil water evaporation and low soil moisture, and consequently early-seral trees exhibited lower midday bulk leaf water potentials $\left(\Psi_{\mathrm{L}}\right)$ relative to late-seral trees $(-1.01 \pm 0.14$ and $-0.54 \pm 0.07 \mathrm{MPa}$, respectively). Although $\Psi_{\mathrm{L}}$ did not differ between evergreen and drought-deciduous trees, results from stable isotope analyses indicated different strategies to overcome seasonal water limitations. Differences were especially pronounced in the early-seral stage where evergreen trees
\end{abstract}

Communicated by Frederick C. Meinzer.

N. J. Hasselquist $(\square)$

Department of Forest Ecology and Management,

Swedish University of Agriculture Sciences (SLU),

90183 Umea, Sweden

e-mail: Niles.Hasselquist@ @seksko.slu.se

N. J. Hasselquist · M. F. Allen · L. S. Santiago

Center for Conservation Biology, University of California,

Riverside, 92521 Riverside, CA, USA

L. S. Santiago

Department of Botany and Plant Sciences,

University of California, Riverside, 92521 Riverside, CA, USA had significantly lower xylem water $\delta^{18} \mathrm{O}$ values relative to drought-deciduous trees $(-2.6 \pm 0.5$ and $0.3 \pm 0.6 \%$, respectively), indicating evergreen species used deeper sources of water. In contrast, drought-deciduous trees showed greater enrichment of foliar ${ }^{18} \mathrm{O}\left(\Delta^{18} \mathrm{O}_{1}\right)$ and ${ }^{13} \mathrm{C}$, suggesting lower stomatal conductance and greater wateruse efficiency. Thus, the rapid development of deep roots appears to be an important strategy enabling evergreen species to overcome seasonal water limitation, whereas, in addition to losing a portion of their leaves, droughtdeciduous trees minimize water loss from remaining leaves during the dry season.

Keywords Groundwater - Resource partitioning · Stable isotopes · Water-use efficiency · Yucatan Peninsula

\section{Introduction}

Seasonally dry tropical forests (SDTF) are widely distributed across the tropics and are characterized by pronounced seasonality in rainfall resulting in seasonal variation in soil water availability (Murphy and Lugo 1986; Mooney et al. 1995). These forests represent roughly $40 \%$ of the landmass covered by all tropical forests (Murphy and Lugo 1986) and cover an estimated area of $1.05 \times 10^{6} \mathrm{~km}^{2}$ (Miles et al. 2006). However, relatively little research has been done in SDTF compared to wet tropical or temperate forests. Because of exceptionally high rates of land-use change, SDTF are considered to be the most threatened of all major tropical forest types, with less than $10 \%$ of mature forest remaining in many areas (Murphy and Lugo 1986; Janzen 1988; Bullock et al. 1995). The primary uses of SDTF have been shifting towards agriculture, selective logging, tree plantations, and conversion to grasslands for 
grazing (Murphy and Lugo 1986). Furthermore, SDTF on the Yucatan Peninsula, Mexico, are subject to natural disturbances such as hurricanes and fire (Boose et al. 2003; Whigham et al. 2003). Consequently, SDTF on the Yucatan Peninsula are characterized by a patchy mosaic of different seral stages (or age classes) of forests undergoing secondary succession.

As a result of decreased soil water availability, a number of trees in SDTF lose a large portion of their leaves during the dry season (drought-deciduous) (Murphy and Lugo 1986). Previous studies demonstrated that deciduous species minimize water loss during rainless periods and therefore dominate drier forests along precipitation gradients in the lowland tropics (Murphy and Lugo 1986; Santiago et al. 2004). Numerous studies have also shown a high degree of vertical partitioning of soil water resources among tropical forest tree species (Jackson et al. 1995, 1999; Meinzer et al. 1999; Querejeta et al. 2007). The degree of soil water partitioning as well as variation in timing of leaf production has therefore been hypothesized to decrease competition and promote tree species coexistence in SDTF. However, the majority of these studies have focused on tree species in mature forests. Early- and lateseral trees experience different abiotic and biotic environments that can differentially alter resource acquisition, growth and survival (Brown and Lugo 1990; Allen et al. 2003a). Consequently, there is a critical need to better understand how trees in different seral stages overcome seasonal water limitations in SDTF.

The Yucatan Peninsula is a low-lying karst platform characterized by shallow soils that have limited water storage capacity (Weidie 1985; Weisbach et al. 2002). Trees must therefore endure 4-6 months of low soil water availability in the strongly seasonal dry climate on the northern Yucatan Peninsula. Despite these seasonal water limitations, some native trees maintain their foliage during the dry season, suggesting they have access to a more permanent water source, such as groundwater (Benjamin et al. 2001). Schenk and Jackson (2002) showed that rooting depth in the tropics is positively correlated with the length of the dry season, which suggests that deep rooting may be functionally important for trees in SDTF. At the El Eden Ecological Reserve, where this research was conducted, the permanent groundwater table is $4-5 \mathrm{~m}$ from the soil surface (Allen et al. 2003b). Other studies have shown tree species sending roots to water tables at similar or greater depths in a number of different ecosystems (Canadell et al. 1996 and references therein; Farrington et al. 1996; Zencich et al. 2002). It is therefore often assumed that trees, especially evergreen tree species on the northern Yucatan Peninsula, use groundwater to overcome water limitations during the dry season. However, in studies near Merida, Yucatan, where the water table is deeper (9-20 m depth), evergreen trees appeared to utilize water sources stored in the limestone bedrock and not groundwater (Querejeta et al. 2007).

Traditionally, the sources of water used by trees in tropical forests have been difficult to determine because of the large and intricate root biomass and high species diversity characteristic of these ecosystems. However, advances in stable isotope techniques have enabled researchers to more accurately determine water sources for individual plants (Ehleringer and Dawson 1992; Brunel et al. 1995). During water uptake and transport within woody tissue, the oxygen isotopic signature $\left(\delta^{18} \mathrm{O}\right)$ of plant xylem water remains unaltered, and therefore reflects the various zone(s) and depth(s) from which plants extract soil water (White et al. 1985; Dawson and Ehleringer 1991). Because of limited precipitation during the dry season, the upper soil layers become enriched in the heavier isotopes $\left({ }^{18} \mathrm{O}\right)$ due to evaporative fractionation, thereby creating a vertical gradient in the oxygen isotopic signature with soil depth (Barnes and Turner 1998). The oxygen isotopic signature of xylem water can therefore be compared to the $\delta^{18} \mathrm{O}$ signature of water found throughout the soil profile to better understand the sources of water used by individual plants (Ehleringer and Dawson 1992; Jackson et al. 1995; Bonal et al. 2000; Querejeta et al. 2007).

Additionally, the stable isotopic composition of bulk leaf material can be used to infer photosynthetic gas exchange properties. The carbon isotopic composition of plant material $\left(\delta^{13} \mathrm{C}\right)$ is linearly related to the ratio between the partial pressure of $\mathrm{CO}_{2}$ in the leaf intercellular spaces and that of ambient air. Thus, foliar $\delta^{13} \mathrm{C}$ provides a useful index for assessing intrinsic water-use efficiency (WUE), which is the ratio of photosynthetic carbon fixation to stomatal conductance (Farquhar et al. 1982, 1989; see Dawson et al. 2002). The oxygen isotopic composition of plant organic material $\left(\delta^{18} \mathrm{O}\right)$, on the other hand, provides a time-integrated measure of stomatal conductance when other sources of variation (mainly source water $\delta^{18} \mathrm{O}$ ) are minimized (Saurer et al. 1997; Barbour and Farquhar 2000; Barbour et al. 2000; Barbour 2007; Farquhar et al. 2007). The $\delta^{18} \mathrm{O}$ signature of plant tissue is determined by the integrated leaf-to-air vapor pressure gradient during transpiration (Farquhar et al. 1998) and is strongly influenced by the plant physiological response to changes in environmental conditions such as atmospheric humidity and soil moisture (Powers et al. 2009). Thus, the simultaneous measurements of $\delta^{13} \mathrm{C}$ and $\delta^{18} \mathrm{O}$ in leaf organic material can help separate the independent effects of carbon fixation and stomatal conductance on $\delta^{13} \mathrm{C}$ because both $\delta^{18} \mathrm{O}$ and $\delta^{13} \mathrm{C}$ are impacted by stomatal conductance, whereas $\delta^{18} \mathrm{O}$ is unaffected by photosynthetic rate (Keitel et al. 2003; Scheidegger et al. 2000; Grams et al. 2007; Sullivan and Welker 2007). 
Table 1 List of tree species used in this study

\begin{tabular}{|c|c|c|c|c|}
\hline Species & Family & Common names (Maya) & Leaf phenology & Peak leaf fall \\
\hline Caesalpinia gaumeri Greenm. & Fabaceae & Kitam che' & Drought-deciduous & March-April \\
\hline Lonchocarpus castilloi Standley & Fabaceae & Chashté & Drought-deciduous & March-April \\
\hline Lysiloma latisiliquum (L.) Benth. & Fabaceae & Tsalam & Drought-deciduous & March-April \\
\hline Coccoloba diversifolia Jacq. & Polygonaceae & Bojom & Evergreen & - \\
\hline Esenbeckia pentaphylla (Macfad.) Griseb. & Rutaceae & Tankax ché & Evergreen & - \\
\hline Vitex gaumeri Greenm. & Verbenaceae & Yaax niik & Evergreen & - \\
\hline
\end{tabular}

All six species are found throughout the three seral stages on the Northern Yucatan Peninsula, Mexico. Three of the six tree species represent drought-deciduous leaf phenology and lose their leaves in March-April. The other three species are evergreen and maintain their leaves during the dry season

In this study, we examined the water status of six canopy tree species, representing contrasting leaf phenology (evergreen vs. drought-deciduous) at three seral stages along a fire chronosequence on the northern Yucatan Peninsula. We also present isotope data on plant xylem water $\left(\delta^{18} \mathrm{O}\right)$, foliar carbon $\left(\delta^{13} \mathrm{C}\right)$, and enrichment of foliar $\delta^{18} \mathrm{O}$ relative to source water $\left(\Delta^{18} \mathrm{O}_{1}\right)$ in order to better understand strategies trees use to overcome water limitations during the dry season. We hypothesized that trees in the early-seral stage would exhibit lower bulk leaf water potentials as a result of using shallower water sources compared to trees in the late-seral stage that have access to deeper sources of water. We also hypothesized that evergreen trees would use deeper water sources from deeper soil layers relative to drought-deciduous trees, whereas drought-deciduous trees would have higher foliar $\Delta^{18} \mathrm{O}_{1}$ and $\delta^{13} \mathrm{C}$ values, indicating reduced stomatal conductance and subsequently greater WUE.

\section{Materials and methods}

Study site

The study was carried out at El Eden Ecological Reserve, a 2,500-ha seasonal tropical forest reserve located in the northeastern corner of the Yucatan Peninsula, Mexico $\left(21^{\circ} 12.61^{\prime} \mathrm{N}, 87^{\circ} 10.93^{\prime} \mathrm{W}\right)$. The mean annual temperature of the site is $24.2^{\circ} \mathrm{C}$. The region receives an average of $1,650 \mathrm{~mm}$ of annual precipitation with a wet season from May to December. The dry season is from January to April when precipitation is $<100 \mathrm{~mm}$ per month. The soils at the Reserve are shallow $(<20 \mathrm{~cm})$ with ca $30 \%$ soil organic matter, $\mathrm{pH} 7.5$, bulk density of $0.35 \mathrm{~g} / \mathrm{cm}^{3}$, and overlay limestone bedrock (Allen et al. 2003a; Vargas and Allen 2008).

The vegetation of the Reserve is described in Schutlz (2005), and consists of a mosaic of seral stages undergoing different stages of secondary succession (Allen et al. 2003b; Hasselquist et al. 2010). For this study, we selected three different seral stages representing a chronosequence of secondary succession ranging in age from an area burned 9 years previously (early-seral stage), an area burned 18 years previously (mid-seral stage) to an area that had not been disturbed for more than 60 years (late-seral stage). All seral stages of the chronosequence were located within a distance of $5 \mathrm{~km}$. Greater detail on the site characteristics can be found in Vargas et al. (2008).

\section{Sampling}

Plant and soil/bedrock samples were collected simultaneously within each seral stage in April 2007. We selected six tree species representing contrasting leaf phenology (evergreen vs. drought-deciduous) for isotopic analyses (Table 1). These species were chosen because they are abundant across the site and are found throughout the chronosequence. The reason that all three drought-deciduous species were from a single family is because the majority of the drought-deciduous species at our site belong to the Fabaceae family. The limitation to this sampling scheme is that physiological variation between species with evergreen versus drought-deciduous phenology could be the result of divergences deep in the phylogenetic tree. However, this would largely reflect the variation of phenological strategies at our site because of the preponderance of legumes. Within each seral stage, measurements were made on three representative trees for each species giving us a total of 18 trees per seral stage. The diameter at breast height (DBH) was measured for all trees. During the peak of the dry season, we measured midday (1200-1400 hours) bulk leaf water potentials on leafy twigs $\left(\Psi_{\mathrm{L}}\right)$ using a Scholander-type pressure chamber (model 1000; Plant Moisture Stress, Corvallis, OR, USA). Measurements of $\Psi_{\mathrm{L}}$ were made over three consecutive days, with measurements from trees in each seral stage taken each day to reduce any bias associated with sampling dates. For stable isotope analyses of xylem water, suberized twigs approximately $10 \mathrm{~mm}$ in diameter and $50-80 \mathrm{~mm}$ long were cut from individual trees. Stem 
samples were collected at $150 \mathrm{~cm}$ height or from the lower branches in taller trees to minimize any bias based on location within the canopy. Clipped twigs were immediately placed in a capped vial, wrapped in parafilm and stored in the freezer until water extraction for stable isotope analyses.

Soil samples were collected by inserting a $4.5-\mathrm{cm}-$ diameter metal soil corer until we encountered limestone bedrock (usually $<10 \mathrm{~cm}$ in depth). Within each seral stage, five samples were randomly collected for water content determination and stable isotope analyses of soil water. To characterize all possible water sources, bedrock samples were also collected from two local wells within the Reserve. Bedrock samples were collected at least $15 \mathrm{~cm}$ deep (horizontally) into the sidewalls of the wells to minimize the alteration of water isotopic composition by evaporative enrichment. Samples were collected using a hand-held chisel at 25, 50, 75, 100, 150, 200 and $300 \mathrm{~cm}$ depths. From each well, two samples were collected at each depth from opposite sidewalls. Freshly collected soil and bedrock samples were placed in capped vials, wrapped in parafilm and stored in the freezer until water extraction for stable isotope analyses. Three groundwater samples were also collected from each well.

\section{Stable isotope analyses}

Water was extracted from plant and soil/bedrock samples using a cryogenic vacuum distillation line (Ehleringer et al. 2000). Soil water content was calculated as [(fresh weight - dry weight)/dry weight $\times 100$ ] according to differences in sample weight before and after thorough water extraction $\left(100^{\circ} \mathrm{C}, 3 \mathrm{~h}\right) \cdot \delta^{18} \mathrm{O}$ values were obtained by equilibration of $50 \mu \mathrm{l}$ of the extracted water with $2 \%$ $\mathrm{CO}_{2}$ for $48 \mathrm{~h}$. The isotopic composition of the $\mathrm{CO}_{2}$ gas was then determined using an isotope ratio mass spectrometer running in the continuous flow mode (Finnigan MAT Delta Plus XL; Thermo Instruments, Bremen, Germany) at the Center for Stable Isotope Biogeochemistry of the University of California at Berkeley. All $\delta^{18} \mathrm{O}$ values are expressed in delta notation (\%) relative to the internationally accepted standard (Vienna Standard Mean Oceanic Water, VSMOW). Analytical precision of the $\delta^{18} \mathrm{O}$ measurements was $0.22 \%$.

In late April 2007, sunlit leaf samples were collected from individual trees included in the water source determination study for foliar $\delta^{13} \mathrm{C}$ and $\delta^{18} \mathrm{O}$ analyses. For drought-deciduous trees, we used newly formed foliar tissue produced during the dry season. Five mature leaves were collected from the top of the each individual tree and pooled into a single sample. Leaves were oven dried at $70^{\circ} \mathrm{C}$ for $48 \mathrm{~h}$, finely ground, and analyzed for $\delta^{13} \mathrm{C}$ and $\delta^{18} \mathrm{O}$ at the Center for Stable Isotope Biogeochemistry of the University of California, Berkeley. Analysis of $\delta^{13} \mathrm{C}$ was performed with a PDZ Europa 20/20 isotope ratio mass spectrometer (Manchester, UK). Oxygen isotope analysis was conducted on a Finnigan MAT Delta PlusXL (Finnigan MAT, Bremen, Germany) following the methods of Farquhar et al. (1997). All $\delta^{13} \mathrm{C}$ are expressed in delta notation (\%) relative to the internationally accepted standard (PeeDee Belemnite, PDB). Analytical precision for carbon and oxygen isotope analyses were 0.17 and $0.23 \%$, respectively.

Variation in the isotope composition of source water was removed from the oxygen isotope composition of plant foliage by presenting the compositions as enrichments relative to source water $\left(\Delta^{18} \mathrm{O}_{1}\right)$ as described by Barbour et al. (2000).

$\Delta^{18} \mathrm{O}_{\mathrm{l}}=\delta^{18} \mathrm{O}_{\mathrm{l}}-\delta^{18} \mathrm{O}_{\mathrm{s}}$

where $\delta^{18} \mathrm{O}_{1}$ is the oxygen isotope composition of organic matter. Because the $\delta^{18} \mathrm{O}$ signature of plant xylem water remains unaltered during uptake and transport within woody tissue, we assumed that the $\delta^{18} \mathrm{O}$ signature of source water $\left(\delta^{18} \mathrm{O}_{\mathrm{s}}\right)$ was equal to the $\delta^{18} \mathrm{O}$ of plant xylem water.

Statistical analyses were conducted using SPSS statistical software (v.16.0; SPSS, 2007). Soil water content and soil water $\delta^{18} \mathrm{O}$ values were subjected to a one-way ANOVA followed by post hoc test using Bonferroni corrections to determine significant $(P<0.05)$ differences among seral stages. Bulk leaf water potential, xylem water $\delta^{18} \mathrm{O}$, and foliar $\delta^{13} \mathrm{C}$ and $\Delta^{18} \mathrm{O}_{1}$ data were subjected to a two-way ANOVA followed by post hoc tests using Bonferroni corrections to detect significant $(P<0.05)$ differences among trees representing contrasting leaf phenology (evergreen vs. drought-deciduous) and seral stages. Leastsquare regression was also used to examine relationships among measured variables.

\section{Results}

During March and April, only $107 \mathrm{~mm}$ of rain was recorded representing $5 \%$ of the total rainfall during the 12 months prior to soil/bedrock sampling (Fig. 1). Gravimetric water content in the upper $300 \mathrm{~cm}$ of the soil/bedrock profile fluctuated between 13 and 18\%, and no clear trend with soil depth was observed (Fig. 2a). The large standard errors associated with mean soil/bedrock water content values reflects the heterogeneous nature of the profile, which is composed of soil pockets interspersed within an intricate matrix of limestone bedrock with varying water holding capacity. The pronounced seasonality in rainfall favored the development of a vertical gradient in $\delta^{18} \mathrm{O}$ throughout the soil/bedrock profile (Fig. 2b). Average $\delta^{18} \mathrm{O}$ values of soil/ bedrock samples decreased abruptly from an average 


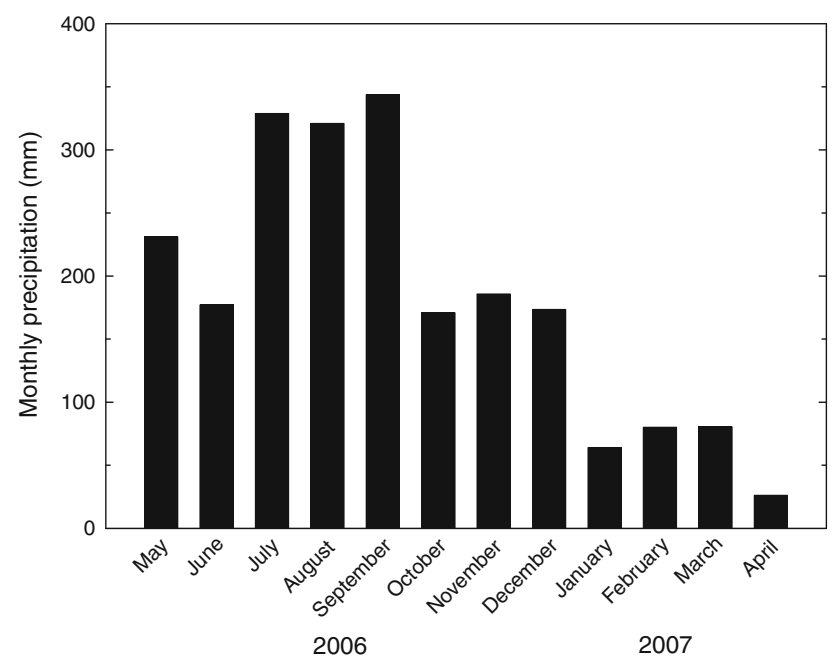

Fig. 1 Monthly rainfall distribution during May 2006-April 2007 at El Eden Ecological Reserve, which is located in the northeastern corner of the Yucatan Peninsula, Mexico

$4.13 \pm 0.33 \%$ at $5 \mathrm{~cm}$ depth to $-1.93 \pm 0.20 \%$ at $75 \mathrm{~cm}$. Between 75 and $300 \mathrm{~cm}$ depth, bedrock samples became progressively depleted in ${ }^{18} \mathrm{O}$, and at $300 \mathrm{~cm}$ depth the average $\delta^{18} \mathrm{O}$ value of bedrock water was no longer significantly different than groundwater $\left(F_{1,8}=2.47\right.$, $P=0.16)$. Groundwater samples yielded an average $\delta^{18} \mathrm{O}$ value of $-4.19 \pm 0.21 \%$.

Differences in measured variables among seral stages are summarized in Table 2. Tree height and DBH differed significantly among seral stages $(P<0.001$ for both). Surface soil water content was significantly greater in the later-seral stage compared to both the early- and mid-seral stages $\left(F_{2,14}=20.85, P<0.001\right)$. Average surface soil water $\delta^{18} \mathrm{O}$ values were significantly higher in the earlyand mid-seral stages relative to the late-seral stage $\left(F_{2,14}=6.74, P=0.01\right)$. Trees in the early-seral stage had significantly lower $\Psi_{\mathrm{L}}$ values compared to trees in the lateseral stage $\left(F_{2,48}=3.86, P=0.03\right)$. Trees in the mid-seral stage had significantly lower xylem water $\delta^{18} \mathrm{O}$ values compared to trees in the early-seral stage $\left(F_{2,48}=4.07\right.$, $P=0.02$ ). Foliar $\delta^{13} \mathrm{C}$ values were significantly higher for trees in the early-seral stage relative to trees in the mid- and late-seral stage $\left(F_{2,48}=9.12, P<0.001\right)$. Trees in the early-seral stage had significantly higher $\Delta^{18} \mathrm{O}_{1}$ values compared to trees in the late-seral stage $\left(F_{2,48}=3.52\right.$, $P=0.04)$.

Bulk leaf water potential did not differ between evergreen and drought-deciduous trees within any of the seral stages $(P>0.05$; Fig. 3a). Differences in xylem water $\delta^{18} \mathrm{O}$ between evergreen and drought-deciduous trees were only significant in the early-seral stage $(P<0.05)$, whereas no differences were detected in the mid- and lateseral stages (Fig. 3b). When comparing among droughtdeciduous trees, xylem water $\delta^{18} \mathrm{O}$ values were significantly lower in the mid- and late-seral stages relative to the early seral stage $(P<0.05$, Fig. $3 b)$. We also found a negative correlation between DBH and xylem water $\delta^{18} \mathrm{O}$ values among the drought-deciduous trees $\left(r^{2}=0.15\right.$, $P=0.05$ ), suggesting that larger, drought-deciduous trees had access to deeper water sources. For evergreen trees, xylem water $\delta^{18} \mathrm{O}$ values did not differ among seral stages $(P>0.05$; Fig. $3 b)$, nor was there a significant relationship between DBH and xylem water $\delta^{18} \mathrm{O}$ values $\left(r^{2}=0.02, P=0.54\right)$.
Fig. 2 Mean $( \pm S E)$ water content (a) and oxygen isotope $\left(\delta^{18} \mathrm{O}\right)$ signature $(\mathbf{b})$ throughout the soil/bedrock profile during the peak of the dry season in April 2007. Values at $5 \mathrm{~cm}$ depth represent the overall average from the three seral stages $(n=15)$, whereas values at deeper depths represent the average of four soil/bedrock samples collected from two wells. The crossed bar represents the mean $( \pm \mathrm{SE}) \delta^{18} \mathrm{O}$ signature of groundwater $(n=6)$

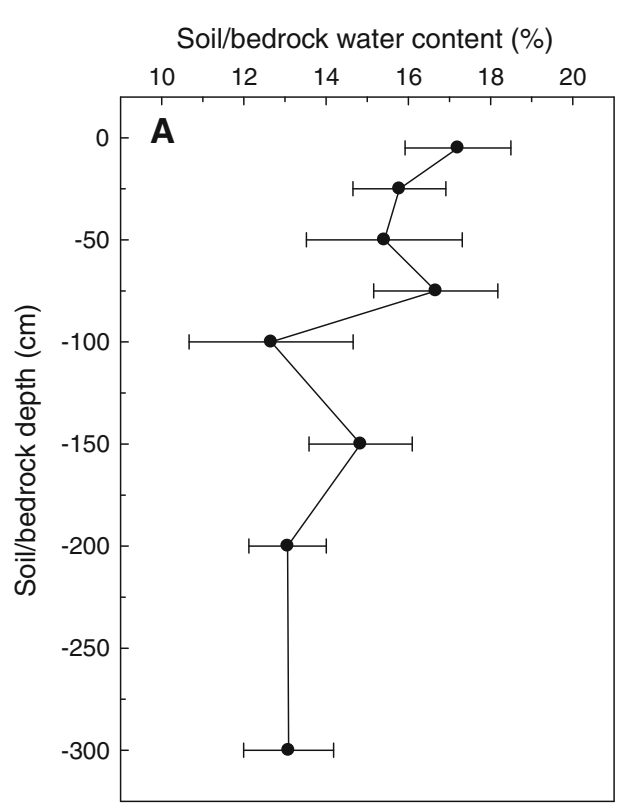


As observed for xylem water $\delta^{18} \mathrm{O}$ values, differences in foliar $\delta^{13} \mathrm{C}$ between evergreen and drought-deciduous trees were only significant in the early-seral stage $(P<0.05$; Fig. $3 \mathrm{c})$. When comparing among droughtdeciduous trees, foliar $\delta^{13} \mathrm{C}$ values were significantly lower in the mid- and late-seral stages relative to the early-seral stage $(P<0.05)$; whereas foliar $\delta^{13} \mathrm{C}$ values for evergreen trees did not differ among seral stages $(P>0.05$; Fig. 3c). We found a positive correlation between stem water $\delta^{18} \mathrm{O}$ and foliar $\delta^{13} \mathrm{C}$ values among the droughtdeciduous species $\left(r^{2}=0.16, P=0.04\right)$, suggesting that drought-deciduous trees using shallower water sources had greater WUE.

Differences in $\Delta^{18} \mathrm{O}_{1}$ between evergreen and droughtdeciduous trees were only significant in the early-seral stage $(P<0.05)$, whereas no differences were detected in the midand late-seral stages $(P>0.05$; Fig. $3 \mathrm{~d})$. When comparing among drought-deciduous trees, there was a general trend of decreasing $\Delta^{18} \mathrm{O}_{1}$ values among the seral stages, which resulted in significantly lower $\Delta \Delta^{18} \mathrm{O}_{1}$ values in the late-seral stage relative to the early-seral stage $(P<0.05$; Fig. $3 d)$. When combining all seral stages, we found a positive correlation between foliar $\delta^{13} \mathrm{C}$ and $\Delta^{18} \mathrm{O}_{1}$ values among drought-deciduous trees $\left(r^{2}=0.23, P=0.01\right.$; Fig. 4). However, when comparing within individual seral stages, the relationship between foliar $\delta^{13} \mathrm{C}$ and $\Delta^{18} \mathrm{O}_{1}$ values was only significant for drought-deciduous species in the midseral stage $\left(r^{2}=0.46, P=0.04\right)$.

\section{Discussion}

Results from this study suggest that trees in different seral stages experience significant differences in soil water availability during the dry season. In general, it appeared that trees in the early-seral stage experienced lower soil water availability relative to trees in the lateseral stage. Although there were no differences in $\Psi_{\mathrm{L}}$ between evergreen and drought-deciduous trees, results from stable isotope analyses suggest that evergreen and drought-deciduous trees use different strategies to overcome seasonal water limitations, especially in the earlyseral stage with lower soil water availability. Based on differences in xylem water $\delta^{18} \mathrm{O}$ values, it appeared that evergreen trees used deeper sources of water compared to drought-deciduous trees in the early-seral stage. In contrast, higher foliar $\delta^{13} \mathrm{C}$ and $\Delta^{18} \mathrm{O}_{1}$ values for droughtdeciduous trees relative to evergreen trees in the earlyseral stage suggested that drought-deciduous species had greater WUE as a result of reduced stomatal conductance during the dry season.

Based on the combination of lower surface soil water content, lower $\Psi_{\mathrm{L}}$, and high foliar $\delta^{13} \mathrm{C}$ values, trees in the 
Fig. 3 Mean bulk leaf water potential (a), xylem water $\delta^{18} \mathrm{O}$ values (b), foliar $\delta^{13} \mathrm{C}$ values (c), and enrichment of foliar $\delta^{18} \mathrm{O}$ relative to source water (d) for evergreen and droughtdeciduous species among different seral stages. Values in each seral stage represent the average $(n=9)$ and $95 \%$ confidence intervals
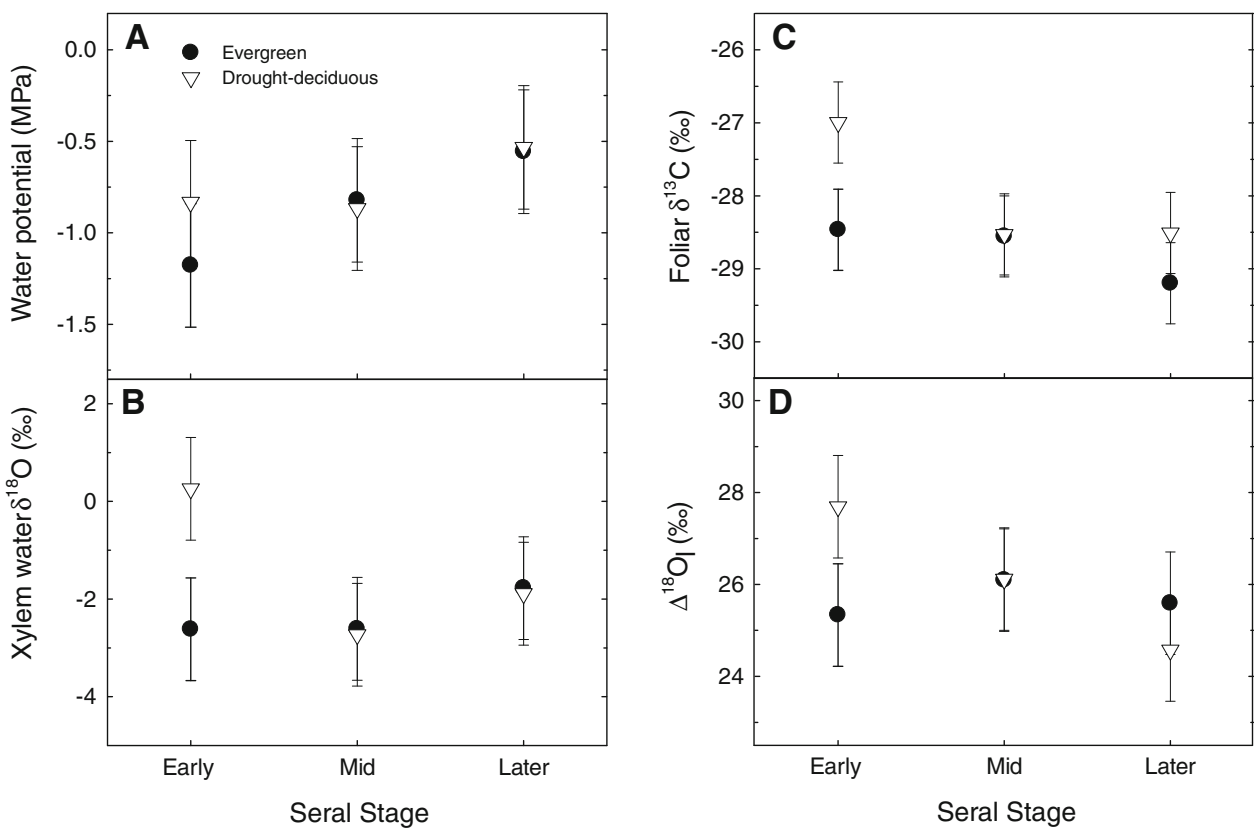

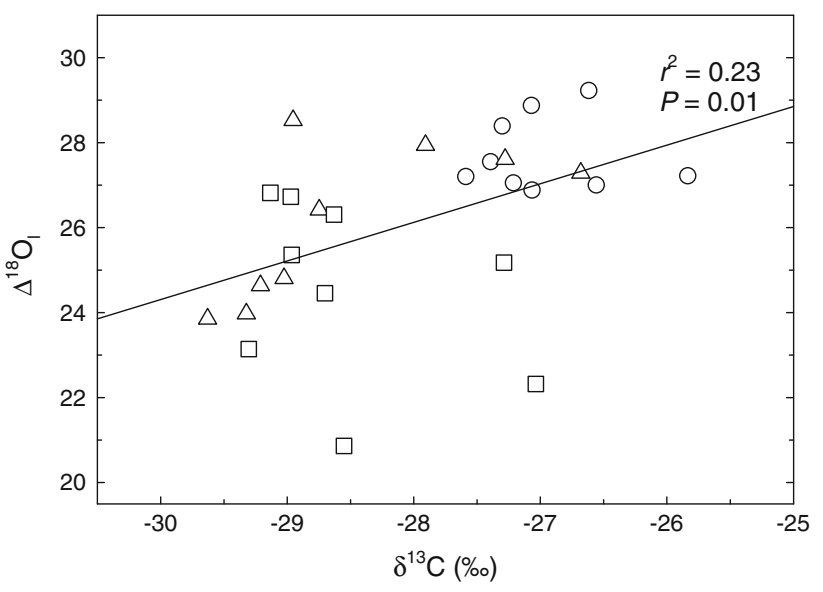

Fig. 4 Correlation between foliar $\delta^{13} \mathrm{C}$ and $\Delta^{18} \mathrm{O}_{1}$ values among drought-deciduous trees. Circles trees in the early-seral stage; triangles trees in the mid-seral stage; squares trees in the late-seral stage

early-seral stage appeared to operate under greater water deficit than trees in the late-seral stage. Given the close proximity and interspersed structure of the seral stages, it is unlikely that differences in surface soil water content resulted from differential precipitation among seral stages. However, extremely high density of trees $<1 \mathrm{~cm}$ DBH combined with greater root biomass in the early-seral stage (Vargas et al. 2008) create greater demands on surface soil moisture, consistent with our finding of lower soil water content in the early-seral stage (Table 2). High $\delta^{18} \mathrm{O}$ values of surface soil water in the early-seral stage indicated increased rates of evaporation from the soil surface (Allison 1982; Allison and Hughes 1983). Allison and Hughes
(1983) previously showed that water loss from the soil surface was greater beneath mallee (native Eucalyptus scrub) than at a cropped site in southern Australia. The authors explained the differences in water loss as the result of a denser plant cover at the cropped site, making evaporation from the soil surface less likely. Similarly, the reduced canopy stature (Allen et al. 2003b) and greater canopy openness (Vargas et al. 2009) in the early-seral stage would have led to increased rates of soil water evaporation, as indicated by high surface soil water $\delta^{18} \mathrm{O}$ values (Table 2). Vargas and Allen (2008) also found increasing surface evaporation following defoliation caused by Hurricane Wilma at the same site.

At the peak of the dry season, we observed a vertical isotopic gradient $\left(\delta^{18} \mathrm{O}\right)$ throughout the soil/bedrock profile (Fig. 2), which in turn allowed us to infer water sources used by trees. Contrary to our initial expectation, trees in the late-seral stage did not appear to use deeper sources of water than trees in the early-seral stage. The lack of difference in water sources between trees in the early- and late-seral stages may, in part, be related to differences in the amount of water stored in the shallow soils. Surface soil water content was roughly two times greater in the late-seral stage relative to the early-seral stage (Table 2), and therefore represented a substantial source of water for trees in the late-seral stage. Additionally, because the most limiting nutrients for plant growth are greatest in the upper portion of the soil profile (Jobbágy and Jackson 2001), soil water partitioning in late-seral trees may reflect a necessary trade-off resulting from higher nutrient demand associated with maintenance of an extensive canopy. 
Only in the early-seral stage did we observe vertical partitioning of water sources among evergreen and drought-deciduous trees with evergreen trees using deeper sources of water than drought-deciduous trees (Fig. 3b). Similarly, Jackson et al. (1995) and Meinzer et al. (1999) have shown evergreen species tapping deeper water sources compared to drought-deciduous species in a SDTF in Panama. It is therefore possible that deep roots may free evergreen species from the constraint of shedding their leaves during the dry season. Interestingly, there was no correlation between tree size (as measured by DBH) and xylem water $\delta^{18} \mathrm{O}$ values for evergreen trees, which is consistent with previous studies in SDTF (Jackson et al. 1999; Querejeta et al. 2007). Jackson et al. (1999) hypothesized that rapid development of deep roots may facilitate the establishment and survival of small trees by allowing them to maintain relatively constant rates of water use. Meinzer et al. (1999) reported that smaller trees preferentially tapped deeper sources of water relative to larger trees, and conjectured that the presence of deep roots in smaller trees would substantially reduce the probability of mortality during the dry season. Thus, our finding of significantly lower xylem water $\delta^{18} \mathrm{O}$ values for evergreen species in the early-seral stage combined with the lack of correlation between tree DBH and xylem water $\delta^{18} \mathrm{O}$ values provides further evidence for the importance of evergreen species to rapidly develop deep roots as a strategy to overcome seasonal water limitations.

Significantly higher foliar $\delta^{13} \mathrm{C}$ values for trees in the early-seral stage relative to trees in the mid- and late-seral stage could, in part, be explained by differences in microclimate, leading to variation in soil moisture and vapour pressure deficit (VPD) among the seral stages (Table 2). Korol et al. (1999) found a positive correlation between foliar $\delta^{13} \mathrm{C}$ and mean annual VPD, suggesting that trees responded to a drier environment by stomatal closure, whereas stomata remained open in environments with higher humidity. Ehleringer and Copper (1988) showed that foliar $\delta^{13} \mathrm{C}$ values increased with decreasing water availability along a soil moisture gradient in the Sonoran Desert, indicating that WUE increased as soil water availability decreased. At our site, Goode and Allen (2009) previously reported higher VPD in the early-seral stage relative to the late-seral stage $(0.60$ and $0.46 \mathrm{kPa}$, respectively). Furthermore, Goode et al. (2010) found that epiphytes in the late-seral stage exhibited bulk leaf tissue and extractable sugars that were depleted in ${ }^{13} \mathrm{C}$, indicating lower VPD and possibly a greater shift from crassulacean acid metabolism to increasing $\mathrm{C}_{3}$ photosynthesis relative to epiphytes in early-seral stages at this site. Thus, the combination of higher VPD and lower soil moisture in the early-seral stage might be the cause for higher foliar $\delta^{13} \mathrm{C}$ values in this seral stage.
Drought-deciduous trees in the early-seral stage had the greatest WUE, as indicated by the highest foliar $\delta^{13} \mathrm{C}$ values, and the lowest stomatal conductance, as indicated by the highest $\Delta^{18} \mathrm{O}_{1}$ values, among all seral stages (Fig. 3c, d). In contrast, drought-deciduous trees in the late-seral stage had the lowest WUE, as indicated by the lowest foliar $\delta^{13} \mathrm{C}$, and the highest stomatal conductance, as indicated by the lowest $\Delta^{18} \mathrm{O}_{1}$ values (Fig. 3c, d). Drought-deciduous trees in the mid-seral stage had stomatal conductance and WUE values that fell inbetween those found in the early- and late-seral stages. Furthermore, when combining drought-deciduous trees for all seral stages, we found a positive correlation between foliar $\delta^{13} \mathrm{C}$ and $\Delta^{18} \mathrm{O}_{1}$ (Fig. 4), suggesting that greater WUE was the result of reduced stomatal conductance. According to the conceptual model developed by Scheidegger et al. (2000), high foliar $\delta^{13} \mathrm{C}$ values for drought-deciduous trees, in combination with higher tissue $\delta^{18} \mathrm{O}$ values, can be interpreted as evidence for enhanced water stress and stomatal limitation to photosynthesis (Sternberg et al. 1989). It is important to note that several factors other than leaf level gas exchange, especially variation in mesophyll conductance and mean VPD, could contribute to such isotopic variability (Seibt et al. 2008). However, in this study, it appeared that for drought-deciduous trees stomatal regulation is an important strategy for minimizing evaporative water loss during the dry season.

In conclusion, we have shown that trees on the northern Yucatan Peninsula experience a wide range of soil water availability during secondary succession. Moreover, it appeared that evergreen and drought-deciduous trees use different strategies to overcome seasonal water limitations, which in turn may decrease competition and promote tree species coexistence in the dry tropical climate on the northern Yucatan Peninsula. These differences were especially pronounced in the early-seral stage with lower soil water availability, whereas we found no differences between evergreen and drought-deciduous trees in the midand late-seral stages. In the early seral stage, evergreen trees appeared to use deeper sources of water as a strategy to overcome seasonal water limitations. Drought-deciduous trees, on the other hand, in addition to losing their leaves, had reduced stomatal conductance that resulted in greater WUE of remaining leaves as a strategy to overcome water limitations during the dry season.

Acknowledgments We thank El Eden Ecological Reserve for their continued support and access to their research facilities. We are also grateful to Laurel Goode and Juan Castillo for their help in the field. This research was supported by grants from National Science Foundation awarded to MF Allen (DEB-9981607, DEB-0615427, and EF0410408) and LS Santiago (DEB-0770 6813), and from a University of California Institute for Mexico and the United States dissertation research grant awarded to N. J. Hasselquist. 
Open Access This article is distributed under the terms of the Creative Commons Attribution Noncommercial License which permits any noncommercial use, distribution, and reproduction in any medium, provided the original author(s) and source are credited.

\section{References}

Allen EB, Allen MF, Egerton-Warburton L, Corkidi L, GómezPompa A (2003a) Impacts of early- and late-seral mycorrhizae during restoration in seasonal tropical forest, Mexico. Ecol Appl 13:1701-1717

Allen EB, Violi HA, Allen MF, Gómez-Pompa A (2003b) Restoration of tropical seasonal forest in Quintana Roo. In: Gómez-Pompa A, Allen MF, Fedick SL, Jimenez-Osornio JJ (eds) The lowland Maya: three millennia at the human-wildland interface. Haworth Press, Binghamton, pp 587-598

Allison $\mathrm{G}$ (1982) The relationship between ${ }^{18} \mathrm{O}$ and deuterium in water in sand columns undergoing evaporation. J Hydrol 55:163-169

Allison G, Hughes MW (1983) The use of natural tracers as indicators of soil-water movement in a temperate semiarid region. J Hydrol 60:157-173

Barbour MM (2007) Stable oxygen isotope composition of plant tissue: a review. Funct Plant Biol 34:83-94

Barbour MM, Farquhar GD (2000) Relative humidity and ABAinduced variation in carbon and oxygen isotope ratios of cotton leaves. Plant Cell Environ 23:473-485

Barbour MM, Fischer RA, Sayre KD, Farquhar GD (2000) Oxygen isotope ratio of leaf and grain material correlates with stomatal conductance and yield in irrigated, field-grown wheat. Aust J Plant Physiol 27:671-679

Barnes CJ, Turner JV (1998) Isotopic exchange in soil water. In: Kendall C, McDonnell JJ (eds) Isotope tracers in catchment hydrology. Elsevier, Amsterdam, pp 137-164

Benjamin TJ, Montañez PI, Jiménez JJM, Gillespie AR (2001) Carbon, water, and nutrient flux in Maya homegardens in the Yucatan peninsula of Mexico. Agrofor Syst 53:103-111

Bonal D, Atger C, Barigah TS, Ferhi A, Guehl JM, Ferry B (2000) Water acquisition patterns of two wet tropical canopy trees of French Guiana as inferred from $\mathrm{H}_{2}^{18} 0$ extraction profiles. Ann For Sci 57:717-724

Boose ER, Foster DR, Plotkin AB, Hall B (2003) Geographical and historical variation in hurricanes across the Yucatan Peninsula. In: Gómez-Pompa A, Allen MF, Fedick SL, Jimenez-Osornio JJ (eds) The lowland Maya: three millennia at the human-wildland interface. Haworth Press, Binghamton, pp 495-515

Brown S, Lugo AE (1990) Tropical secondary forests. J Trop Ecol $6: 1-32$

Brunel JP, Walker GR, Kenneth-Smith AK (1995) Field validation of isotopic procedures for determining sources of water used by plants in a semiarid environment. J Hydrol 167:351-368

Bullock SH, Mooney HA, Medina E (1995) Seasonally dry tropical forests. Cambridge University Press, Cambridge

Canadell J, Jackson RB, Ehleringer JR, Mooney HA, Sala OE, Schulze ED (1996) Maximum rooting depth of vegetation at the global scale. Oecologia 108:583-595

Dawson TE, Ehleringer JR (1991) Streamside trees that do not use stream water. Nature 50:335-337

Dawson TE, Mambelli S, Plamboeck AH, Templer PH, Tu KP (2002) Stable isotopes in plant ecology. Annu Rev Ecol Syst 33:507-559

Ehleringer JR, Copper TA (1988) Correlations between carbon isotope ratio and microhabitat in desert plants. Oecologia 76:562-566
Ehleringer JR, Dawson TE (1992) Water uptake by plants: perspectives from stable isotope composition. Plant Cell Environ 15:1073-1082

Ehleringer JR, Roden J, Dawson TE (2000) Assessing ecosystemlevel water relation through stable isotope analyses. In: Sala OE, Jackson RB, Mooney HA, Howarth RW (eds) Methods in ecosystem science. Springer, New York, pp 181-198

Farquhar GD, O'Leary MH, Berry JA (1982) On the relationship between carbon isotope discrimination and intercellular carbon dioxide concentrations in leaves. Aust J Plant Physiol 9:121-137

Farquhar GD, Ehleringer JR, Hubick KT (1989) Carbon isotope discrimination and photosynthesis. Annu Rev Plant Phys 40:503-537

Farquhar GD, Henry BK, Styles JM (1997) A rapid on-line technique for determination of oxygen isotope composition of nitrogencontaining organic matter and water. Rapid Commun Mass Spectrom 11:1554-1560

Farquhar GD, Barbour MM, Henry BK (1998) Interpretation of oxygen isotope composition of leaf material. In: Griffiths $\mathrm{H}$ (ed) Stable isotopes. BIOS Scientific, Oxford, pp 95-101

Farquhar GD, Cernusak LA, Barnes B (2007) Heavy water fractionation during transpiration. Plant Physiol 143:11-18

Farrington P, Turner JV, Gailitis V (1996) Tracing water uptake by jarrah (Eucalyptus marginata) trees using natural abundances of deuterium. Trees 11:9-15

Goode LK, Allen MF (2009) Seed germination conditions and implications for establishment of an epiphyte, Aechmea bracteata (Bormeliaceae). J Ecol 204:179-188

Goode LK, Erhardt EB, Santiago LS, Allen MF (2010) Carbon stable isotopic composition of soluble sugars in Tillandsia epiphytes varies in response to shifts in habitat. Oecologia (in press). doi: 10.1007/S00442-010-1577-5

Grams TEE, Kozovitz AR, Häberle K-H, Matyssek R, Dawson TE (2007) Combining $\delta^{13} \mathrm{C}$ and $\delta^{18} \mathrm{O}$ analyses to unravel competition, $\mathrm{CO}_{2}$ and $\mathrm{O}_{3}$ effects on the physiological performance of different-aged trees. Plant Cell Environ 30:327-339

Hasselquist NJ, Santiago LS, Allen MF (2010) Belowground nitrogen dynamics in relation to hurricane damage along a tropical dry forest chronosequence. Biogeochemistry 98:89-100

Jackson PC, Cavelier J, Goldstein G, Meinzer FC, Holbrook NM (1995) Partitioning of water resources among plants of a lowland tropical forest. Oecologia 101:197-203

Jackson PC, Meinzer FC, Bustamante M, Goldstein G, Franco A, Rundel PW, Caldas L, Igler E, Causin F (1999) Partitioning of soil water among tree species in a Brazilian Cerrado ecosystem. Tree Physiol 19:717-724

Janzen DH (1988) Tropical dry forests: the most endangered major tropical ecosystem. In: Wilson EO (ed) Biodiversity. National Academy of Sciences/Smithsonian Institution, Washington, DC, pp 130-137

Jobbágy EG, Jackson RB (2001) The distribution of soil nutrients with depth: Global patterns and the imprint of plants. Biogeochemistry 53:51-77

Keitel C, Adams MA, Holst T, Matzarakis A, Mayer H, Rennenberg $\mathrm{H}$, Gessler A (2003) Carbon and oxygen isotope composition of organic compounds in the phloem sap provides a short-term measure for stomatal conductance of European beech (Fagus sylvatica L.). Plant Cell Environ 26:1157-1168

Korol RL, Kirschbaum MUF, Farquhar GD, Jefferys M (1999) Effects of water status and soil fertility on the C-isotope signature in Pinus radiata. Tree Physiol 19:551-562

Meinzer FC, Andrade JL, Goldstein, Holbrook NM, Cavelier J, Wright SJ (1999) Partitioning of soil water among canopy trees in a seasonally dry tropical forest. Oecologia 121:293-301

Miles L, Newton AC, DeFries RS, Ravilious C, May I, Blyth S, Kapos V, Gordon JE (2006) A global overview of the 
conservation status of tropical dry forests. J Biogeogr $33: 491-505$

Mooney HA, Bullock SH, Medina E (1995) Introduction. In: Bullock SH, Mooney HA, Medina E (eds) Seasonally dry tropical forests. Cambridge University Press, Cambridge, pp 1-8

Murphy PG, Lugo AE (1986) Ecology of tropical dry forest. Annu Rev Ecol Syst 17:67-88

Powers MD, Pregitzer KS, Palik B, Webster CR (2009) Water relations of pine seedlings in contrasting overstory environments. For Ecol Manag 258:1442-1448

Querejeta JI, Estrada-Medina H, Allen MF, Jimenez-Osornio JJ (2007) Water partitioning among trees growing on shallow karst soils in a seasonally dry tropical climate. Oecologia 152:26-36

Santiago LS, Kitajima K, Wright SJ, Mulkey SS (2004) Coordinated changes in photosynthesis, water relations and leaf nutritional traits of canopy trees along a precipitation gradient in lowland tropical forest. Oecologia 139:495-502

Saurer M, Allen K, Siegwolf R (1997) Correlating $\delta^{13} \mathrm{C}$ and $\delta^{18} \mathrm{O}$ in cellulose of trees. Plant Cell Environ 20:1543-1550

Scheidegger Y, Saurer M, Bahn M, Siegwolf R (2000) Linking stable oxygen and carbon isotopes with stomatal conductance and photosynthetic capacity: a conceptual model. Oecologia $125: 350-357$

Schenk HJ, Jackson RB (2002) The global biogeography of roots. Ecol Monogr 72:311-328

Schutlz GP (2005) Vascular flora of the El Eden ecological reserve, Quintana Roo, Mexico. J Torrey Bot Soc 132:311-322

Seibt U, Rajabi, Griffiths H, Berry JA (2008) Carbon isotopes and water use efficiency: sense and sensitivity. Oecologia 155:441-454

Sternberg LSL, Mulkey SS, Wright SJ (1989) Oxygen isotope ratio stratification in a tropical moist forest. Oecologia 81:51-56
Sullivan PF, Welker JM (2007) Variation in leaf physiology of Salix arctica within and across ecosystems in the high arctic: test of a dual isotope $\left(\Delta^{13} \mathrm{C}\right.$ and $\left.\Delta^{18} \mathrm{O}\right)$ conceptual model. Oecologia 151:372-386

Vargas R, Allen MF (2008) Diel patterns of soil respiration in a tropical forest after Hurricane Wilma. J Geophys Res Biogeosci 113:G03021. doi:10.1029/2007JG000620

Vargas R, Allen MF, Allen EB (2008) Biomass and carbon accumulation in a fire chronosequence of a seasonally dry tropical forest. Glob Change Biol 14:109-124

Vargas R, Trumbore SE, Allen MF (2009) Evidence of old carbon used to grow new fine roots in a tropical forest. New Phytol 182:710-718

Weidie AE (1985) Geology of the Yucatan Platform. In: Ward WC et al (eds) Geology and hydrogeology of the Yucatan and Quaternary geology of northeastern Yucatan Peninsula. NOGS, New Orleans, pp 1-19

Weisbach C, Tiessen H, Jiménez-Osornio JJ (2002) Soil fertility during shifting cultivation in the tropical karst soils of Yucatan. Agronomie 22:253-263

Whigham DF, Olmsted I, Cano EC, Curtis AB (2003) Impacts of hurricanes on forests of Quintana Roo, Yucatan Peninsula, Mexico. In: Gómez-Pompa A, Allen MF, Fedick SL, Jimenez-Osornio JJ (eds) The lowland Maya: three millennia at the human-wildland interface. Haworth Press, Binghamton, pp 193-216

White JWC, Cook ER, Lawrence JR, Broecker WS (1985) The D/H ratio of sap in trees: implications for water sources and tree ring D/H ratios. Geochim Cosmochim Acta 49:237-246

Zencich SJ, Froend RH, Turner JV, Gailitis V (2002) Influence of groundwater depth on the seasonal sources of water accessed by Banksia tree species on a shallow, sandy coastal aquifer. Oecologia 131:8-19 